\title{
Assessing urban fire risk in the central business district of Dar es Salaam, Tanzania
}

Yohannes Kachenje Assistant Research Fellow at the Institute of Human Settlement Studies (IHSS), Ardhi University, Dar es Salaam ykachenje2001@yahoo.co.uk

Jacob Kihila Assistant Research Fellow at the Institute of Human Settlement Studies (IHSS), Ardhi University, Dar es Salaam kihilaj@gmail.com

Huba Nguluma Senior Research Fellow at the Institute of Human Settlement Studies (IHSS), Ardhi University, Dar es Salaam huba8660@yahoo.com

\section{ABSTRACT}

Buildings as infrastructure along with people's lives need protection against fire outbreaks. Knowledge on the use of installed facilities is essential in tackling fire emergencies, otherwise their installation becomes meaningless. Lack of such knowledge could hamper escape from fire hazards and thwart attempts to contain fire outbreaks at their preliminary stage. This study, carried out in the Central Business District of Dar es Salaam City, assessed urban fire risk with respect to public awareness on the use of fire fighting facilities and preparedness in the event of fire outbreaks. Public buildings with at least four storeys or $2000 \mathrm{~m}^{2}$ floor space were surveyed. According to the Fire and Rescue Act of 2007, such buildings have to be provided with adequate means of escape and fire fighting facilities. Data was collected through observation and interviews with building managers, users and key informants. The study revealed high fire disaster risk in most buildings of the study area, as $60 \%$ of the buildings' users do not know how to operate the facilities, and $41 \%$ are not aware of the available escape means in case of fire outbreak. Worse still, only $29 \%$ had received training within the past five years, and $68 \%$ had never been trained.

\section{KEYWORDS}

Fire, disaster risk, public awareness, buildings, Dar es Salaam

\section{Introduction}

\section{Background to the Study}

The world has in the past three decades experienced a succession of disasters such as floods, fires, storms, earthquakes, volcanic eruptions and landslides. Such incidents include the worst 
fire disaster that occurred in 1984 in Mexico (Cavallini et al., 2007), the Mozambican floods of the year 2000 (BBC News, 2000) and the 2010 Chilean earthquake (ICRC, 2010). The disasters have claimed many thousands of lives, caused material losses and inflicted a terrible toll on developing countries in particular, where disasters divert attention and resources from development needed desperately to escape poverty (Marjanovic \& Nimpuno, 2002:222). According to Kasarda and Parnell (quoted by Kyessi, 2002:1), currently there is a fast growth in urban places of all sizes from small market centres to mega-cities. The increased developments and interactions increase the potentiality of fire occurrences as well. Thus, all stakeholders, especially the users of the buildings need to be well-equipped in terms of knowledge on how to prevent and react to fire outbreaks.

While inadequate and deteriorating infrastructure is among the most pressing and difficult issues facing the cities and towns of the developing world, in Sub-Saharan Africa rapid urbanisation has outstripped governments' capacities to, among other things, provide basic services and guide urban growth (Kyessi, 2002:2). Such a situation adds to the necessity to improve the management of risks and disasters to protect the highly expensive infrastructure and people's lives.

Tanzania is not an exception, as it has also been experiencing a number of natural and humanmade disasters that have caused losses of lives and property, as well as destruction to the environment (URT, 2004:1). Fire outbreaks that carry the danger of causing disasters have been a concern both in urban and rural areas. In urban areas fire has been occurring in buildings used for various purposes including residential, commercial, educational, office space, as well as other mixed purposes. As such, the frequency of fire outbreaks in buildings/houses is higher than the frequency in other uses/premises. In Dar es Salaam, for instance, fire outbreaks in buildings have accounted for $38.3 \%$ to $55.8 \%$ of all the fire outbreaks in the past four years (see Table 1).

\section{Table 1. Fire outbreaks in buildings in Dar es Salaam}

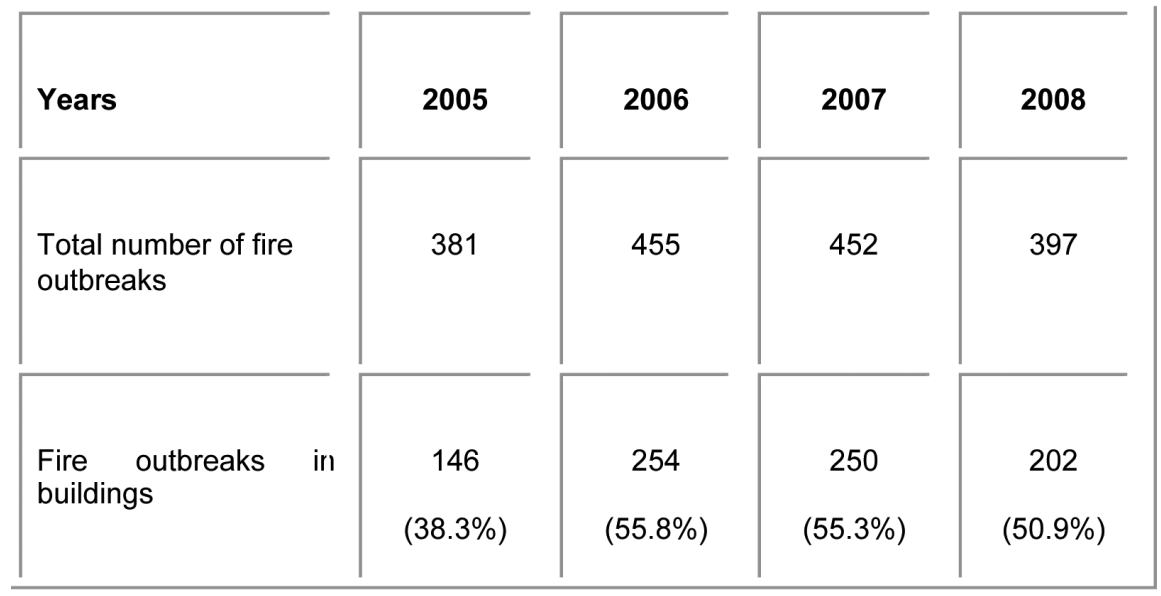


From Table 1 it can be observed that in 2006, 2007 and 2008 fire outbreaks in buildings alone outnumbered the fire outbreaks that occurred in other sites. This being so, deliberate measures are required to address the disaster risk pertaining to fire outbreaks in buildings.

Studies on fire outbreaks have also been conducted in countries other than Tanzania. A survey on high-rise building safety, emergencies and evacuation procedures conducted in Chicago, USA in 2006 indicated that almost all occupants knew where fire exits were located. The findings supported the need for continued public education about emergency evacuation procedures in high-rise buildings (Zmud, 2008:329).

A review of the research on human movement and behaviour in fires (Sime, 1994:63) showed that there had been insufficient research on behaviour in relation to the physical environment and therefore recommended research on "exit choice behaviour". "Exit choice" refers to the provision and distribution of more than one exit of sufficient exit width to allow a population of a specified maximum number (expressed as "occupant capacity" in relation to floor space) time to reach safety in the event of one exit being obstructed by a fire or smoke.

Sime (1994:64) indicated a number of factors that influence people's direction of escape behaviour in the event of a fire. Such factors include the role (staff or public), location (in relation to group members and exits), guidance to exits from staff, affiliate movement in or towards family groups and familiarity with escape routes.

As it can be seen, familiarity with the escape routes is one of the factors that speak of people's safety in the event of fire outbreak. Some of the experiences presented above indicate the need for user/public awareness, both on the availability and the use of the means, particularly the exit doors and exit routes. They also point to some important factors for consideration as far as escape is concerned against fire hazards in buildings.

Limited research has been done in Tanzania to identify the underlying factors for sound management of fire outbreaks. This study was therefore conducted with the aim of generating useful information in the subject area and was focused on fire management capacity in buildings, with emphasis on public awareness related to the availability and use capability of fire fighting facilities.

\section{Description of the research}

Buildings as infrastructure require fire protection to facilitate their regular functioning and service delivery. Protection of buildings is not only necessary for such purposes, but also for the safety of the users. Experience has shown that much emphasis has been placed on ensuring that equipment and various means against fire hazards are put in place in buildings. The Fire Fighting and Rescue Act of 2007 stipulates that every building with more than one storey should be installed with a number of facilities for fire fighting. It does not however compel the building owners to conduct training of the building users so that they can acquire some knowledge on the use of the facilities. Lack of knowledge on how to use the equipment and means against fire hazards could render attempts to contain fire outbreaks at their preliminary stage almost impossible. At the same time such weakness could frustrate escape from fire risks/ 
hazards. This being so, there is a gap in the knowledge on whether or not the said weakness is due to limited awareness and knowledge on fire protection/fighting equipment and means. The fundamental question is: Is the purpose of putting in place fire protection facilities in buildings appropriately realised?

The main objective of the study was to analyse fire management capacity in public buildings, with emphasis on individuals' awareness and knowledge on what they need to do against fire risks and disasters. Specifically the study attempted to identify various types of equipment and means of fire protection/fighting/escape available in the selected public buildings; to explore individuals' awareness and knowledge on the availability and operation of various kinds of equipment and means against fire risks/disasters in selected buildings; to measure the attempts made towards raising fire management awareness and knowledge by institutions/offices; and to analyse the working condition of the equipment and means against fire disaster risks.

The research is considered an integral part of attempts to minimise risks of fire hazards that tend to cause injuries and loss of life and property, including destruction of infrastructure that could serve society, in a number of ways.

\section{Methodology}

The study applied a case study research strategy, where the Central Business District (CBD) of Dar es Salaam was selected as the case study area, owing among other factors to its richness in terms of information relevant to the urbanisation process. Also, selection of the CBD was based on the grounds that it consists of many buildings that are subject to section 22(1) of the Fire Fighting and Rescue Act 14 of 2007. This situation offers a wide range of selection as compared with areas outside the CBD.

The approach to sampling the buildings followed an investigation by Mfinanga (2007), who divided the buildings into three categories, based on land use as purely office buildings, purely commercial buildings, and office and commercial buildings. This study adopted the three categories. However, it added two further categories in an attempt to capture any possibility of variations in awareness regarding the categories on the basis of uses and users. Therefore five categories were considered for data collection and analysis in this study as follows:

(i) Purely office buildings: These are the buildings with $100 \%$ of their respective occupied areas used as offices, without any other activities.

(ii) Purely commercial buildings: These imply buildings that accommodate only commercial activities

(iii) Office and commercial buildings: Office and commercial buildings refer to buildings that accommodate both office and commercial activities.

(iv) Commercial residential buildings: These refer to the buildings that are used for both commercial purposes and for residential accommodation, whether for families or students and workers.

(v) Purely educational buildings: These are used only for educational purposes, involving interaction between teachers/lecturers and students. 
The total number of buildings surveyed was 12 , which is approximately $10 \%$ of the sampling frame. The sampling frame comprises buildings that are four storeys and above and are subject to the Fire and Rescue Act of Tanzania. The survey was conducted in the year 2009.

\section{Data collection methods}

Yin (1994:79) points out that case studies can use several methods of data collection, including interviews, direct observation, documentation, archival records, participant observation and physical artefacts. Methods of data collection applied in this study include interviews and direct observation as follows:

(i) Interviews: This method involved personal interviews and focused interviews. A total of 128 respondents were interviewed. Personal interviews involved administering three different questionnaires, to different respondents, depending on their respective roles and status. The first questionnaire was administered to building owners and managers, particularly estate managers; whereas the second questionnaire was administered to renters and regular users (who are not owners) of the buildings. The third questionnaire involved individual persons visiting the various surveyed buildings. Focused interviews were done with personnel from institutions considered relevant for fire fighting and rescue. The institutions were Ilala Municipal Council, as the surveyed buildings were in Ilala Municipality, and the Fire and Rescue Department for their special role in fire fighting.

(ii) Observation: Non-participant type of observation was applied throughout the field work, hand in hand with taking photographs, aiming at collecting information that did not necessarily require interviews. With this method, the researcher looked at each building's corridors in order to identify the available items of fire fighting equipment and their respective service dates. This gave a clear picture on their functioning capacity, visibility and accessibility for use in case of fire outbreak. The method also served the purpose of triangulating information given by building managers and users on the availability of some facilities such as fire extinguishers, hose reels and emergency exits.

\section{Results and discussion}

\section{Means and equipment available in the buildings}

Based on interviews with managers of the buildings and verification by the researchers, the equipment and means available for fire fighting in the buildings studied include fire extinguishers, hose reels, dry risers, wet risers, sprinklers, smoke/fire detection system/sensors and Manual Call Points (MCPs). Emergency exits linked with alternative staircases were the only means of escape found in the study area. However, their distribution in the respective buildings (Table 2) is not uniform.

\section{Condition of the facilities}

The installed facilities in the buildings studied consist of both facilities in working condition and facilities that are not functioning (see Figure 1 and Table 2). Defective facilities are found in $50 \%$ of the buildings studied, whereas most of the fire extinguishers are working and in good condition. On the other hand, the automatic sensor alarm system is not functioning in most of the buildings. 
Table 2. Means, equipment and their condition

\begin{tabular}{|c|c|c|c|}
\hline \multirow[t]{2}{*}{ Building } & \multirow[t]{2}{*}{ Use of building } & \multicolumn{2}{|l|}{ Equipment available } \\
\hline & & Working & Not working \\
\hline 1. Extelecoms House & Office and commercial & $\begin{array}{l}\text { Fire extinguishers, hose } \\
\text { reels }\end{array}$ & - \\
\hline 2. PPF House & Office and commercial & $\begin{array}{l}\text { Fire extinguishers, hose } \\
\text { reels, automatic } \\
\text { detection system, } \\
\text { sprinkler }\end{array}$ & - \\
\hline 3. IPS Building & Office and commercial & $\begin{array}{l}\text { Fire extinguishers, hose } \\
\text { reel, dry and wet risers }\end{array}$ & - \\
\hline 4. Cooperative Building & Office and commercial & Fire extinguishers & Hose reel \\
\hline 5. NIC Head Office & Office & $\begin{array}{l}\text { Fire extinguisher, Hose } \\
\text { reel, dry riser }\end{array}$ & - \\
\hline 6. Ardhi House & Office & Fire extinguishers & $\begin{array}{l}\text { Fire detection } \\
\text { system }\end{array}$ \\
\hline 7. DIT Admin Block & Education/office & Fire extinguishers & Sprinklers \\
\hline 8. Elimu House & Office & - & Fire extinguishers \\
\hline 9. ATC & Office & Fire extinguishers & \\
\hline 10. TANESCO & Office & Fire extinguisher & $\begin{array}{l}\text { Fire detection } \\
\text { system }\end{array}$ \\
\hline $\begin{array}{l}\text { 11. Institute of Adult } \\
\text { Education }\end{array}$ & Education/office & Fire extinguishers & Hose reel \\
\hline $\begin{array}{l}\text { 12. Kipata (Commercial } \\
\text { residential) }\end{array}$ & Commercial residentia & - & - \\
\hline
\end{tabular}

Fig 1. Condition of the fire fighting facilities.

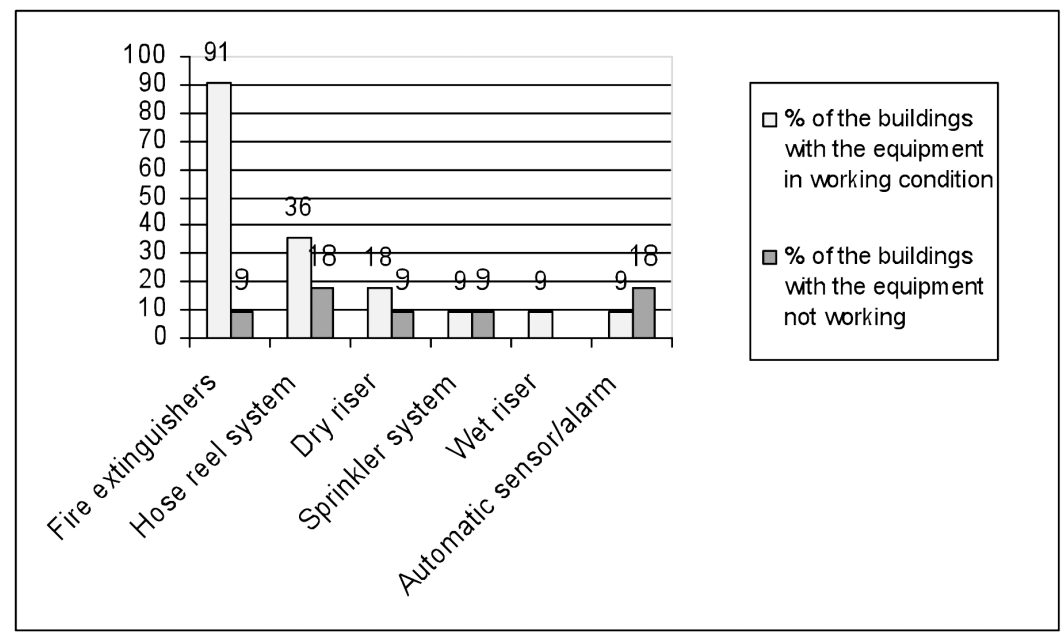


Fig 2. Ardhi House - one of the buildings poorly equipped with fire fighting means and facilities, in addition to limited awareness on the part of its users - a disaster risk!

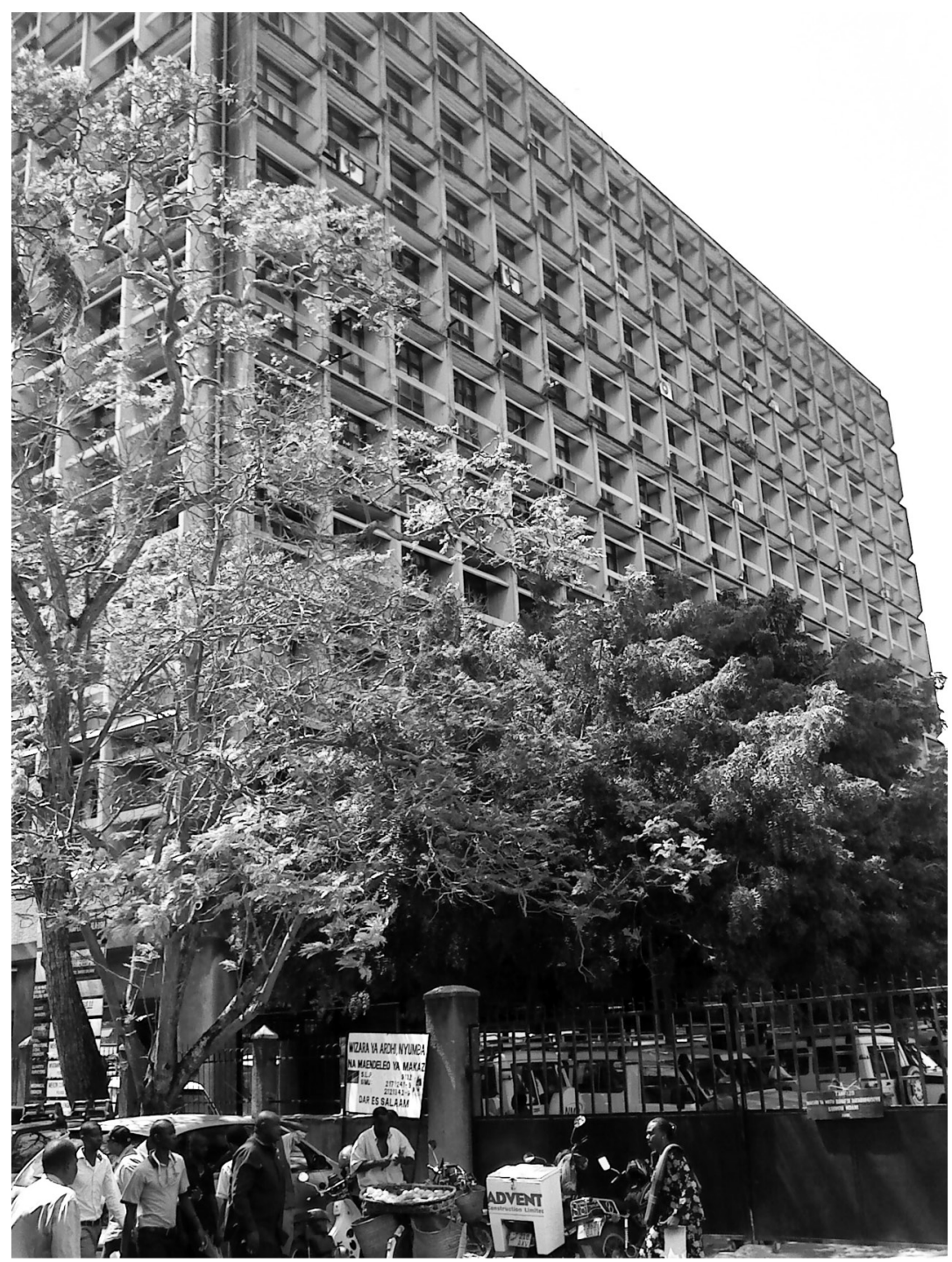

About $50 \%$ of the buildings had some water stored for fire fighting purposes, but only one building was installed with a wet riser system, meaning that the water stored is only meant to assist the fire brigade in the event of a fire.

Observation shows that servicing of the equipment as part of its maintenance is not done regularly. For example, at Elimu House the last service time indicated on the fire extinguishers was the year 2004. This means that the equipment may not be able to work during fire emergencies, as its chemicals have probably already expired.

\section{Situational analysis}

The Fire and Rescue Act, 2007, laid down some guidelines to be used in the buildings including the equipment and means to be provided in the buildings in accordance with their height. 
Table 3 compares what was observed and what is supposed to be provided for each of the buildings visited. As a general observation, most of the buildings do not comply with the requirements of the law.

The Extelecoms, IPS, Cooperative, NIC, Ardhi, Elimu and Institute of Adult Education buildings lack smoke/fire detection systems and automatic sprinkler systems which are a legal requirement for them. Some more deficiencies can be noted as one compares the legal requirements and the current situation. The Fire and Rescue Department is required to supervise adherence to fire protection regulations by all (URT, 2004). It is undoubtedly surprising to see this extent of weakness in compliance with the legislation, while the department concerned is at hand. The Fire and Rescue Department, however, argues that most of the buildings which do not adhere to the legal provisions were constructed before the Fire Fighting and Rescue Acts (1985 and 2007) were in place. Therefore, they need to be given time to adjust to these new provisions. Regulations specifying the grace period granted for the said old buildings have to be formulated as soon as possible.

\section{Table 3. Available facilities and means versus the guidelines}

\begin{tabular}{|c|c|c|c|}
\hline Building & $\begin{array}{l}\text { Highest Storey } \\
\text { floor level from } \\
\text { ground }(\mathrm{m})\end{array}$ & $\begin{array}{l}\text { Means or equipment needed as } \\
\text { per guideline }\end{array}$ & $\begin{array}{l}\text { Means or equipment } \\
\text { installed }\end{array}$ \\
\hline $\begin{array}{l}\text { Extelecoms } \\
\text { House }\end{array}$ & More than $24 \mathrm{~m}$ & $\begin{array}{l}\text { Means of escape } \\
\text { Fire alarm detection system } \\
\text { Automatic fire sprinkler }\end{array}$ & $\begin{array}{l}\text { Fire extinguishers, Hos€ } \\
\text { reel }\end{array}$ \\
\hline PPF House & More than $24 \mathrm{~m}$ & $\begin{array}{l}\text { Means of escape } \\
\text { Fire alarm detection system } \\
\text { Automatic fire sprinkler }\end{array}$ & $\begin{array}{l}\text { Fire extinguishers, hose } \\
\text { reel, automatic } \\
\text { detection system, } \\
\text { sprinkler }\end{array}$ \\
\hline $\begin{array}{l}\text { IPS } \\
\text { Building }\end{array}$ & More than $24 \mathrm{~m}$ & $\begin{array}{l}\text { Means of escape } \\
\text { Fire alarm detection system } \\
\text { Automatic fire sprinkler }\end{array}$ & $\begin{array}{l}\text { Fire extinguishers, hose } \\
\text { reel, dry and wet risers }\end{array}$ \\
\hline $\begin{array}{l}\text { Cooperative } \\
\text { Building }\end{array}$ & More than $24 \mathrm{~m}$ & $\begin{array}{l}\text { Means of escape } \\
\text { Fire alarm detection system } \\
\text { Automatic fire sprinkler }\end{array}$ & $\begin{array}{l}\text { Fire extinguishers, Hos€ } \\
\text { reel }\end{array}$ \\
\hline $\begin{array}{l}\text { NIC Head } \\
\text { Office }\end{array}$ & More than $24 \mathrm{~m}$ & $\begin{array}{l}\text { Means of escape } \\
\text { Fire alarm detection system } \\
\text { Automatic fire sprinkler }\end{array}$ & $\begin{array}{l}\text { Fire extinguisher, Hose } \\
\text { reel, dry riser }\end{array}$ \\
\hline $\begin{array}{l}\text { Ardhi } \\
\text { House }\end{array}$ & More than $24 \mathrm{~m}$ & $\begin{array}{l}\text { Means of escape } \\
\text { Fire alarm detection system } \\
\text { Automatic fire sprinkler }\end{array}$ & $\begin{array}{l}\text { Fire extinguishers, Fire } \\
\text { alarm }\end{array}$ \\
\hline $\begin{array}{l}\text { Elimu } \\
\text { House }\end{array}$ & More than $24 \mathrm{~m}$ & $\begin{array}{l}\text { Means of escape } \\
\text { Fire alarm detection system } \\
\text { Automatic fire sprinkler }\end{array}$ & Fire extinguishers \\
\hline ATC & More than $12 \mathrm{~m}$ & $\begin{array}{l}\text { Means of escape } \\
\text { Fire alarm detection system } \\
\text { Fire extinguishers }\end{array}$ & Fire extinguishers \\
\hline TANESCO & More than $24 \mathrm{~m}$ & $\begin{array}{l}\text { Means of escape } \\
\text { Fire alarm detection system } \\
\text { Automatic fire sprinkler }\end{array}$ & $\begin{array}{l}\text { Fire extinguisher, fire } \\
\text { alarm system }\end{array}$ \\
\hline $\begin{array}{l}\text { Institute of } \\
\text { Adult } \\
\text { Education }\end{array}$ & More than $24 \mathrm{~m}$ & $\begin{array}{l}\text { Means of escape } \\
\text { Fire alarm detection system } \\
\text { Automatic fire sprinkler }\end{array}$ & $\begin{array}{l}\text { Fire extinguishers, hose } \\
\text { reel }\end{array}$ \\
\hline $\begin{array}{l}\text { Kipata } \\
\text { House }\end{array}$ & More than $12 \mathrm{~m}$ & $\begin{array}{l}\text { Means of escape } \\
\text { Fire alarm detection system } \\
\text { Fire extinguishers }\end{array}$ & None \\
\hline
\end{tabular}




\section{Awareness on availability of means and facilities}

Awareness of escape ways' presence and awareness on how to use the various facilities have been singled out in this study. Of all the facilities and means $40.8 \%$ of all the respondents appeared to lack awareness of the existence of emergency exits in the buildings they use. This situation implies that the use of the emergency exits in case of fire outbreak is very unlikely, thus limiting realisation of putting in place such particular facility. Subsequently, in many of the surveyed buildings fire disasters may hardly be escaped using the emergency exits, since many do not know the location of fire exits. A more serious situation was observed in the Institute of Adult Education (administration) building, Ardhi House, IPS Building, DIT (administration) and the Cooperatives Building. The above named buildings have a greater percentage of users $(\geq 50 \%)$ who do not know where the escape ways are located, as Table 4 shows.

Table 4. Building users' awareness of escape ways

\begin{tabular}{|c|c|}
\hline Building name & $\begin{array}{l}\text { Users' awareness on location } \\
\text { of escape ways (\%) }\end{array}$ \\
\hline Institute of Adult Education & 12 \\
\hline Ardhi House & 25 \\
\hline IPS & 28 \\
\hline DIT Admin. & 38 \\
\hline Cooperative & 50 \\
\hline Extelecoms House & 71 \\
\hline Elimu House & 75 \\
\hline TANESCO & 75 \\
\hline ATC House & 78 \\
\hline NIC Head Office & 100 \\
\hline PPF House & 100 \\
\hline
\end{tabular}

Table 4 indicates extreme cases in two buildings (NIC Head Office and PPF House), in which all respondents showed awareness of the existing escape ways. An extremely negative scenario features the Institute of Adult Education, in which only 12\% of the respondents showed awareness of the escape ways. It was also observed that some buildings, especially of commercial residential use in Kipata Street at Kariakoo, lack designed escape ways. In such a situation it could be difficult to facilitate safe escape from fire outbreaks.

However, knowing the location of the escape ways does not necessarily imply easy access through the ways, as one respondent on the third floor of the Cooperative Building hinted: 
"... The escape ways are known to many, but their environment is not welcoming: stairs are old; the exit doors are regularly locked, whereas the keys are with the watchmen downstairs..."

Worse still, the respondent above did not know who among the watchmen held the keys. Two locks were observed on the door, while the grilled outer door was also locked, a situation that presents doubt on their usability for escape purposes during emergencies. Such a situation raises the need for appropriately reconciling safety and security needs.

As regards the availability of fire extinguishers, most regular users of the buildings are aware of their presence in the respective buildings. On average, $75 \%$ of users per building were aware of the existence of fire extinguishers and their respective locations. In the individual buildings the percentages of users who are aware of this most common facility in the buildings surveyed range from 50 to 100 .

\section{Awareness on the use of the provided facilities}

Escape routes/doors and fire fighting facilities are not useful unless users of the buildings know how to use them. An average of $66 \%$ of the respondents did not know how to operate the various items of equipment/facilities available in the buildings surveyed. Table 5 summarises the situation.

\section{Table 5. Ability to use the equipment}

\begin{tabular}{|l|c|}
\hline \multicolumn{1}{|l|}{ Building } & $\begin{array}{l}\text { Users unable to operate } \\
\text { the equipment (\%) }\end{array}$ \\
\hline IPS & 100 \\
\hline PPF House & 100 \\
\hline DIT Admin. & 88 \\
\hline Institute of Adult Education & 88 \\
\hline Ardhi House & 75 \\
\hline Cooperative & 50 \\
\hline Elimu House & 50 \\
\hline TANESCO & 50 \\
\hline Extelecom & 43 \\
\hline ATC house & 23 \\
\hline NIC Head Office & 6 \\
\hline Average & 60 \\
\hline
\end{tabular}


From Table 5 it is further observed that more than $60 \%$ of the buildings surveyed have users who were not able to operate the equipment. On that basis, more risky buildings could be IPS Building, PPF House, DIT (Administration) Block, Ardhi House, Cooperative Building, Elimu House and TANESCO Building. However, further description on internal organisation against fire emergencies distinguishes PPF House (which is the newest of all the surveyed buildings) from the rest of the buildings. In this building there are specially trained fire marshals posted on each floor. In the event of an emergency and other needs the Marshals communicate with trained floor service men, who in turn direct and assist users escape safely from such emergencies. The Marshals are backed with smoke detectors and an automatic alarm system. This system is not found anywhere else in the surveyed buildings. The system's organisation and the skills of the emergency personnel could minimise the need for training all the users, as more reliance could be placed on the emergency personnel. All the same, it is questionable practice to rely solely on the emergency personnel instead of supplementing with training and drills against fire emergencies.

\section{Training and drills}

Lack of training for fire-emergency preparedness was a factor blamed by most of the respondents for their inability to use the various means and equipment, as well as limited knowledge related to fire and rescue. While some complained they had never been trained; others claimed they were trained a long time ago, and others found the training not practical, as it did not involve drills. In the past five years, training was organised in eight of the 12 surveyed buildings, although users/workers who were trained in that period reached an average of only $36 \%$ per building. For all the buildings surveyed, an average of $68 \%$ of the users/workers did not take part in any training at all, while 3\% had been trained in the past 10 or more years. Table 6 summarises the situation.

The situation presented above is not favourable as far as fire safety is concerned, because in many of the buildings the users are unlikely to benefit from the available facilities as they do not know how to operate them.

"... staff are not trained, so in case of fire we cannot use the fire extinguishers though we have them for so long...", lamented one user in the IPS Building.

Little emphasis has been put on training and drills by the managers and owners of buildings, as Table 6 shows, and as observed by an employee in the PPF House, after six years of using the building:

"...Little care has been taken to make sure that all or at least half of the people using the building are trained on how/what to do in case of fire..."

\section{Conclusions and recommendations}

Empirically this research has shown that there is limited fire management capacity in public buildings, as far as public awareness and availability of means and facilities are concerned. It has been observed that most of the buildings have a limited number of facilities and means againstfire hazards, and some of the means and facilities are either not easily accessible or are 
not functioning at all. As such, there is a high 'hidden' disaster risk in most of the buildings.

\begin{tabular}{|c|c|}
\hline Building name & Trained regular users (\%) \\
\hline IPS & 14 \\
\hline PPF House & 25 \\
\hline DIT Admin. & 12.5 \\
\hline Institute of Adult Education & 12.5 \\
\hline Ardhi House & 0 \\
\hline Cooperatives & 50 \\
\hline Elimu House & 25 \\
\hline TANESCO & 50 \\
\hline Extelecom & 50 \\
\hline ATC house & 77.7 \\
\hline NIC Head Office & 80 \\
\hline Kipata House & 0 \\
\hline Average & 33 \\
\hline
\end{tabular}

Table 6. Training of workers/regular users on fire and rescue

A significant number of building users in the city of Dar es Salaam are not aware of the use of fire fighting facilities. Also some of the fire fighting equipment in the buildings is not in good working condition. There is no maintenance program either. The situation in most of the buildings does not comply with a number of stipulations in the Fire and Rescue Act of 2007, despite the existence of the Fire and Rescue Department, which is entrusted with supervision of adherence to fire protection regulations by all. It seems that stakeholders and key actors wait for disasters to occur and take action, rather than acting in a precautionary manner. Training institutions have also a major role to play in terms of knowledge dissemination against fire risks.

It is hereby recommended that the Fire and Rescue Department speeds up awareness programs especially in public buildings on the use and functioning of fire fighting facilities and means of escape to enhance safety in the buildings. In addition, the building owners should establish service and maintenance programs for the fire means and facilities and make sure that there is a regular inspection schedule. The Fire and Rescue Department, local authorities and estate 
managers are very important actors for implementation and monitoring of such programs. Training for the users of the buildings should be regularly conducted and where the local circumstances present difficulty in offering training and drills to workers and other building users, the estate/building managers should put in place fire marshals to take responsibility for the users' and the infrastructure's safety.

The Disaster Management Unit in the Prime Minister's Office, the Ministry of Home Affairs, local authorities as well as the Fire and Rescue Department should collaborate to ensure smooth and quick enforcement of the regulations related to management of fire outbreaks in buildings.

\section{References}

BBC NEWS. 2000. Mozambique: How disaster unfolded. [Web:] http://news.bbc.co.uk/2/hi/africa/655227.stm [Date of access: 12 Apr. 2010].

CAVALLINI, M., PAPAGNI, M.F. \& BARUFFALDI PREIS, F.W. 2007. Fire Disasters in the Twentieth Century. Annals of Burns and Fire Disasters, 20(2):101-103, Jun.

ICRC see INTERNATIONAL COMMITTEE OF THE RED CROSS. 2010.

INTERNATIONAL COMMITTEE OF THE RED CROSS (ICRC). 2010. Haiti earthquake 2010. [Web:] http://www.icrc.org/web/doc/siterfl0.nsf/htmlall/familylinks-haiti-eng. [Date of access: 12 Apr. 2010].

KYESSI, A.G. 2002. Community Participation in Urban Infrastructure Provision, Servicing Informal Settlement in Dar es Salaam. Dortmund: SPRING Centre, University of Dortmund. (Dissertation D.Phil.) 405 p.

MARJANOVIC, P. \& NIMPUNO, K. 2002. Disaster Management: Living with risk - towards effective disaster management training in Africa. [Web:] http://www.tt.fh-koeln.de/semesterprojects_extern/disaster_managment/data_lit/Disaster_Management/DM_living_with_risk.pdf [Date of access: 16 Feb. 2009].

MFINANGA, D.A. 2007. Parking generation by facilities in the CBD of Dar es Salaam City. The Journal of Building and Land Development, 14(2):83-99, Dec.

SIME, J. 1994. Escape behaviour in fires and evacuations. (In Stollard, P. \& Johnston, L., eds. Design against Fire, an introduction to fire safety engineering design. London: E \& FN SPON. p. 56-87.)

UNITED REPUBLIC OF TANZANIA (URT). 2004. National Disaster Management Policy. Dar es Salaam: Government Printers. 
UNITED REPUBLIC OF TANZANIA (URT). 2007. Fire and Rescue Act 14 of 2007. Dar es Salaam: Government Printers.

\section{URT see UNITED REPUBLIC OF TANZANIA}

YIN, R.K. 1994. Case Study Research, Design and Methods. London: SAGE. 171 p.

ZMUD, M. 2008. Public Perceptions of High-rise Building Emergency Evacuation Preparedness. Fire Technology. 44:329-336, Apr. 